УДК 631.52:633:114:631.67 (477.7)

DOI https://doi.org/10.32848/agrar.innov.2021.10.19

\title{
УСПАДКУВАННЯ ВИСОТИ РОСЛИН ГІБРИДАМИ ПШЕНИЦІ ОЗИМОЇ РІЗНОГО ЕКОЛОГО-ГЕНЕТИЧНОГО ПОХОДЖЕННЯ В УМОВАХ ЗРОШЕННЯ
}

\author{
ЖУПИНА А.Ю. - здобувач ступеня доктора фрілософії \\ https://orcid.org/0000-0002-3630-7579 \\ Інститут зрошуваного землеробства Національної академії аграрних наук України \\ БАЗАЛІЙ Г.Г. - кандидат сільськогосподарських наук, старший науковий співробітник \\ https://orcid.org/0000-0003-2842-0835 \\ Інститут зрошуваного землеробства Національної академії аграрних наук України \\ усик Л.О. - кандидат сільськогосподарських наук, старший науковий співробітник \\ https://orcid.org/0000-0002-9710-0758 \\ Інститут зрошуваного землеробства Національної академії аграрних наук України \\ МАРЧЕНКО Т.Ю. - доктор сільськогосподарських наук, старший науковий співробітник \\ http://orcid.org/0000-0001-6994-3443 \\ Інститут зрошуваного землеробства Національної академії аграрних наук України \\ ЛАВРИНЕНКО Ю.О. - доктор сільськогосподарських наук, професор, академік НААН \\ http://orcid.org/0000-0001-9442-8793 \\ Інститут зрошуваного землеробства Національної академії аграрних наук України
}

Постановка проблеми. Пшениця озима в Південному Степу $€$ основною зерновою культурою у сівозмінах. Вона досить посухостійка, проте ефективно реагує на штучне зрошення, збільшуючи урожайність у 2-3 рази. Традиційна селекція пшениці озимої на півдні була спрямована на адаптованість до несприятливих агрокліматичних умов, що пов'язано, перш за все, з посухою. Особливої актуальності цей напрям набув в останні десятиліття під тиском змін клімату у напряму посушливості. Одним із природних біологічних засобів адаптованості рослин до посухи є скорочення тривалості періоду вегетації. Селекція на скоростиглість використовується у всіх регіонах, що потерпають від дефіциту вологи. Такий напрям селекції призвів до того, що за останні роки сорти пшениці озимої стали на 3 доби скоростиглішими [1]. Скоростиглі сорти швидко впроваджуються у виробництво, проте і швидко зникають з обігу, коли їх переважають за урожайністю більш пізньостиглі. За оптимального режиму зрошення є можливість використовувати більш пізньостиглі сорти з підвищеним потенціалом урожайності, тому за умов зрошення необхідно використовувати можливість залучення до гібридизації і доборів більш пізньостиглих генотипів західноєвропейського екотипу з подовженим періодом вегетації та підвищеним потенціалом урожайності.

Аналіз останніх досліджень і публікацій. За останні десятиліття урожайність зернових культур у світовому масштабі значно зросла. Збільшення урожайності проходило переважно за рахунок селекційно-генетичного поліпшення сортового складу, підвищення потенціалу продуктивності генотипів, адаптивності до мінливості агроекологічних чинників, толерантності до стресових факторів біотичного та абіотичного походження. Це підкреслює важливість основного напряму в підвищенні продуктивності - селекційно-генетичних розробок, які, за свідченнями провідних вчених, забезпечують основний приріст урожайності та валових зборів в останні роки [2-4].
Україна має потужний потенціал у виробництві зерна, тому на сьогодні важливим напрямом наукового забезпечення галузі рослинництва $€$ створення високоадаптивних сортів агрокліматичної орієнтації з високим ступенем генетичного захисту врожаю від біотичних і абіотичних факторів середовища, розробка наукових основ створення генетично запрограмованих сортів заданої біологічної та господарської орієнтації [5, с. 102-103].

У селекції на адаптивність важливого значення набувають такі ознаки, як дата цвітіння, дата колосіння, дата стиглості, висота рослин. Дослідженнями показано, що найбільш інформативними ознаками для розрізнення ліній були довжина головного колосу, кількість зерен з колосу, дата цвітіння і дата колосіння. Можливість диференціації усіх генотипів, що були відмінними за алелями генів короткостебловості, за комплексом агрономічних ознак не залежала від генетичного фону [6].

Оскільки висота рослини - ознака, яка пов'язана зі стійкістю до вилягання, то негативне домінування $€$ бажаною і селекційно цінною характеристикою. Через полігенний генетичний контроль цієї ознаки немає можливості проводити жорсткий добір у ранніх поколіннях, оскільки за проміжного успадкування в наступних поколіннях можна отримати низькоросліші рослини, які становлять інтерес для селекції на короткостебловість [7].

Детермінація довжини стебла рослинами $\mathrm{F}_{1}$ пшениці м'якої озимої, створеними за участі різних екотипів мала різноманітний характер. За схрещування напівкарликових батьківських форм у більшості спостерігалося позитивне наддомінування. У гібридів, створених за участі середньорослих генотипів з напівкарликовими успадкування відбувалося за позитивним домінуванням. При залученні до гібридизації середньорослих форм характерним було від'ємне наддомінування. Виявлено різноманітний характер успадкування в $F_{1}$ порядкових міжвузлів довжини стебла залежно від компонентів, які були залучені до гібридизації. В досліджуваних попу- 
ляціях $\mathrm{F}_{2}$ відбувалося розщеплення за висотою рослин 3 коливанням генотипів від карликових до середньорослих, відображуючи значний формотворчий процес. Розподіл рослин за висотою залежить від підбору батьківських форм. Залучення до гібридизації з місцевими адаптованими сортами інших екотипів дозволяє створювати значний резерв генотипової мінливості за довжиною стебла [8].

У теорії добору важливо визначитись з поколінням гібридів. Результати більшості досліджень свідчать про можливість починати добір в селекційному процесі за цінними господарськими ознаками з другого покоління [9].

Мета статті. Встановити характер успадкування ознаки «висота рослин», тривалість періоду «цвітіння стиглість» у гібридів пшениці озимої, створених із залученням пізньостиглих зразків західноєвропейського екотипу. Встановити кореляції цих показників з урожайністю зерна відібраних сімей.

Матеріали і методи досліджень. Польові дослідження проведені в Інституті зрошуваного землеробства НААН у 2016-2021 рр. Об'єктом досліджень були сучасні сорти пшениці озимої селекції Інституту, колекційні зразки західноєвропейського екотипу, що були інтродуковані з Франції (номера реєстрації Кф №...-16), та гібриди, створені за їх участі. Сорти та гібриди висівались при зрошенні схемою «материнська форма батьківська, гібрид». Біометричні виміри, обліки урожайності, характеристику успадковуваності ознак гібридами проводили за загальновизнаними методиками [10-12]. Проведені добори елітних рослин 3 популяцій $\mathrm{F}_{2}$ висівали в селекційних розсадниках за облікової площі 0,3 м². Площа облікової ділянки в контрольному розсаднику $4 \mathrm{~m}^{2}$, повторення дворазове. Методи - польові, лабораторні, селекційно-генетичні, статистичні.

Результати досліджень. У схему схрещувань були залучені місцеві сорти селекції інституту та західноєвропейського екотипу (шифр колекції Кф-16). Всі залучені західноєвропейські сорти були меншими за висотою рослин, з подовженим терміном виколошування та дозрівання. Висота залучених іноземних сортів коливалась в межах 82-96 см (табл. 1).

У першому поколінні висота рослин гібридів успадковувалась переважно за проміжним типом. Істинний гетерозис спостерігався у двох комбінацій - Кф 6-16 / Овідій, Кф 9-16 / Овідій та Кошова / Кф 2-16. У всіх інших комбінацій спостерігали часткове домінування позитивне та негативне. Найвищим гібридом першого покоління був гібрид Кф 6-16 / Овідій (114,0 см) зі ступенем істинного гетерозису $16,8 \%$. У другому поколінні спостерігався незначний гетерозис за висотою, проміжне успадкування та домінування низькорослих батьків. I тільки гібридна комбінація Кошова / Кф 2-16 зберегла достатньо високий рівень істинного гетерозису $-21,6 \%$.

Проведені індивідуальні добори в популяціях другого покоління дозволили оцінити ефективність залучення екологічно віддалених батьківських компонентів.

Проведення оцінок відібраних сімей за висотою рослин, термінами проходження фраз розвитку та уро- жайності зерна в селекційних розсадниках дозволили з'ясувати рівень зв'язків окремих ознак та визначити найбільш вагомі маркерні для проведення доборів та корегування моделі сорту. Так, у ліній (сімей) з гібридної популяції Кошова / Кф 2-16 залежність урожайності зерна і тривалості періоду «цвітіння-стиглість» була відсутня, що вказує на можливість проводити добори високопродуктивних генотипів незалежно від групи стиглості. Більш урожайними були скоростиглі лінії, що можливо враховувати при індивідуальних відборах в популяціях цієї комбінації.

Кореляція між висотою рослин і тривалістю періоду «цвітіння стиглість» у цієї комбінації була більш помітною (рис. 2). Подовження вегетації сімей цієї комбінації призводить до зростання висоти рослин, що не є позитивною ознакою такої залежності. Це підтверджує рис. 3, де показаний негативний вплив збільшення висоти рослин селекційних ліній на урожайність зерна.

Таким чином, у гібридної комбінації Кошова / Кф 2-16 не підтвердилась гіпотеза про збільшення урожайності зерна при доборах на подовжений термін періоду формування зерна та наливу (цвітіння-стиглість).

У ліній, відібраних з популяції Кф 5-16 / Ледя подовження тривалості періоду «цвітіння - стиглість» призводила до помірного підвищення урожайності (рис. 4). Підвищення урожайності понад 10 т/га стає можливим з високою ймовірністю при подовженні тривалості періоду «цвітіння-стиглість» понад 51 добу, що свідчить про можливість ефективних доборів на урожайність за подовженою тривалістю вегетації.

Проте в цій популяції до пониження урожайності однозначно призводить висота рослин (рис. 5), тому у цій комбінації необхідно проводити добори низькорослих форм в розріджених популяціях, оскільки в загущених ценозах короткостеблові форми будуть втрачати продуктивність колоса через конкуренцію.

у більшості проаналізованих доборів з гібридних популяцій збільшення висоти рослин призводить до зменшення урожайності (рис. 5), а збільшення тривалості вегетації - до збільшення висоти рослин (рис. 6), тому для кожної гібридної популяції, що створена за участі контрастних за висотою і тривалістю вегетації батьківських компонентів, необхідно розробляти специфрічний план доборів з урахуванням внутрішньопопуляційних кореляційних залежностей маркерних та результативних ознак.

У більшості гібридних популяцій все ж таки спостерігалась позитивна слабка залежність подовження тривалості терміну формування та наливу зернівки з урожайністю зерна, що передбачає перспективність доборів на подовження тривалості вегетації в умовах зрошення (рис. 7, 8).

Аналіз мінливостей окремих морфологічних, господарських та вегетаційних ознак в кожної гібридної популяції, що створена за участі контрастних батьківських форм, можуть бути певні специфічні оптимуми прояву кількісних ознак, що відповідають за формування урожайності зерна майбутніх сортів пшениці м'якої озимої (табл. 2), тому при доборах на високу урожайність зерна 


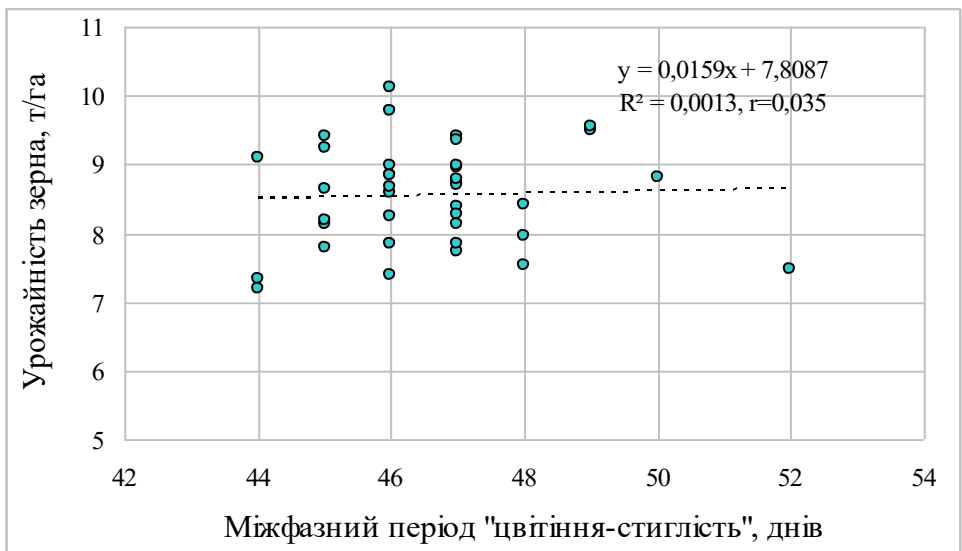

Puc. 1. Кореляційно-регресійна модель залежності урожайності зерна і тривалості міжфазного періоду «цвітіння-стиглість» у ліній з популяції Кошова / Кф 2-16

Таблиця 1

Успадкування ознаки «висота рослин» гібридами F1, F2 пшениці озимої (2016-2018 рр.)

\begin{tabular}{|c|c|c|c|c|c|c|}
\hline \multirow[b]{2}{*}{ Сорт, гібрид } & \multicolumn{3}{|c|}{$F_{1}$} & \multicolumn{3}{|c|}{$F_{2}$} \\
\hline & $\begin{array}{c}\text { Висота } \\
\text { рослин, см }\end{array}$ & $\begin{array}{c}\text { Ступінь } \\
\text { домінування, hp }\end{array}$ & $\begin{array}{c}\text { Ступінь } \\
\text { гетерозису, } \\
\text { Г іст, \% }\end{array}$ & $\begin{array}{c}\text { Висота } \\
\text { рослин, } \\
\text { см }\end{array}$ & $\begin{array}{c}\text { Ступінь } \\
\text { домінування, hp }\end{array}$ & $\begin{array}{c}\text { Ступінь } \\
\text { гетерозису, } \\
\text { Г іст, \% }\end{array}$ \\
\hline q Кф2-16 & 83,1 & & & 83,2 & & \\
\hline Ов Овідій & 98,8 & & & 87,6 & & \\
\hline Кф2-16 / Овідій & 98,5 & 0,96 & $-0,30$ & 82,5 & $-1,32$ & $-5,82$ \\
\hline 우 Ko4-16 & 75,9 & & & 79,1 & & \\
\hline Ов Овідій & 98,9 & & & 87,6 & & \\
\hline Кф4-16 / Овідій & 92,7 & 0,46 & $-6,27$ & 94,5 & 2,62 & 7,88 \\
\hline q Kфp6-16 & 96,7 & & & 93,9 & & \\
\hline ๙ Овідій & 98,4 & & & 87,6 & & \\
\hline Кф6-16 / Овідій & 114,9 & 20,41 & 16,77 & 90,9 & 0,05 & $-3,19$ \\
\hline q К Кр7-16 & 91,7 & & & 85,6 & & \\
\hline О Овідій & 98,9 & & & 87,6 & & \\
\hline Кф7-16 / Овідій & 95,9 & 0,17 & $-3,03$ & 90,9 & 4,30 & 3,77 \\
\hline q Кф8-16 & 89,6 & & & 80,4 & & \\
\hline ○ Овідій & 98,3 & & & 87,6 & & \\
\hline Кф8-16 / Овідій & 98,5 & 1,05 & 0,20 & 87,5 & 0,97 & $-0,11$ \\
\hline q Кф9-16 & 88,6 & & & 90,3 & & \\
\hline ๙ Овідій & 98,9 & & & 87,6 & & \\
\hline Кф9-16 / Овідій & 103,2 & 1,83 & 4,35 & 87,7 & $-0,93$ & $-2,88$ \\
\hline ㅇ Kфр10-16 & 83,7 & & & 80,5 & & \\
\hline Ов Овідій & 98,8 & & & 87,6 & & \\
\hline Кф10-16 / Овідій & 88,9 & $-0,31$ & $-10,02$ & 89,5 & 1,53 & 2,17 \\
\hline q Кф2-16 & 91,3 & & & 86,0 & & \\
\hline$\delta \times \sigma / 0$ & 101,9 & & & 94,1 & & \\
\hline Кф2-16 / Хб/о & 97,6 & 0,19 & $-4,22$ & 94,3 & 1,05 & 0,21 \\
\hline$q$ Xб/0 & 97,3 & & & 88,7 & & \\
\hline స Кф2-16 & 88,6 & & & 76,0 & & \\
\hline Хб/о / Кф2-16 & 91,2 & $-0,40$ & $-6,27$ & 90,7 & 1,31 & 2,25 \\
\hline ф Кошова & 79,8 & & & 79,1 & & \\
\hline ठ Кфр2-16 & 88,4 & & & 76,0 & & \\
\hline Кошова / Кф2-16 & 101,4 & 4,02 & 14,71 & 96,2 & 12,03 & 21,62 \\
\hline Ф Фp№5 & 82,4 & & & 81,8 & & \\
\hline о Ледя & 116,5 & & & 99,5 & & \\
\hline Кф5-16 / Ледя & 100,2 & 0,04 & $-13,99$ & 101,3 & 1,20 & 1,81 \\
\hline q Kф4-16 & 85,2 & & & 83,7 & & \\
\hline ऽ Овідій & 101,7 & & & 86,3 & & \\
\hline Кф4-16 x Овідій & 96,2 & 0,33 & $-5,41$ & 94,6 & 7,35 & 9,56 \\
\hline
\end{tabular}




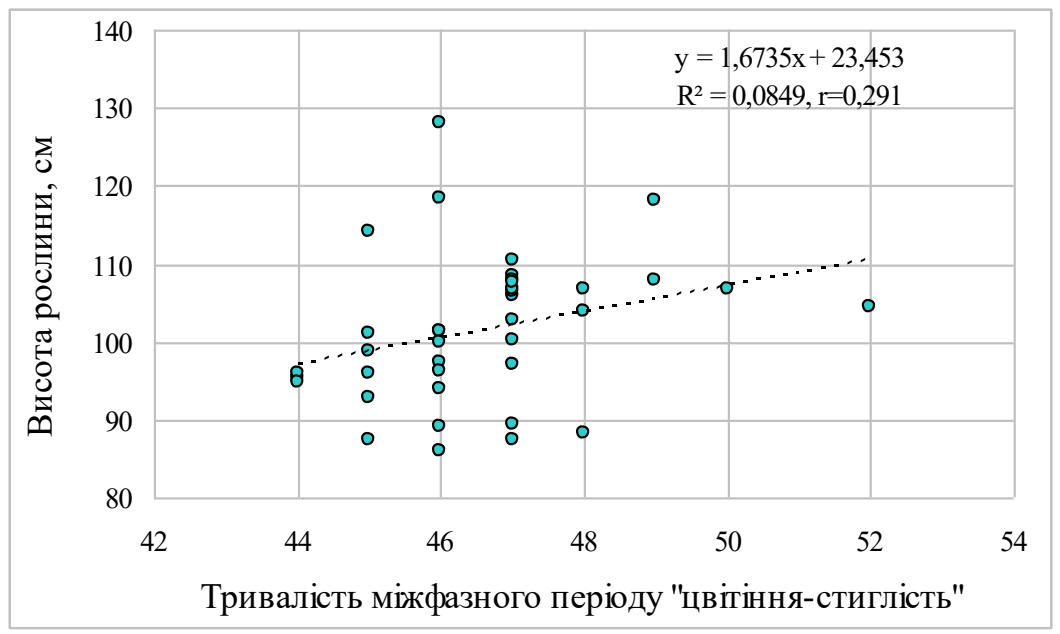

Puc. 2. Кореляційно-регресійна модель залежності тривалості міжфазного періоду «цвітіння-стиглість» і висоти рослини у ліній з популяції Кошова / Кф 2-16

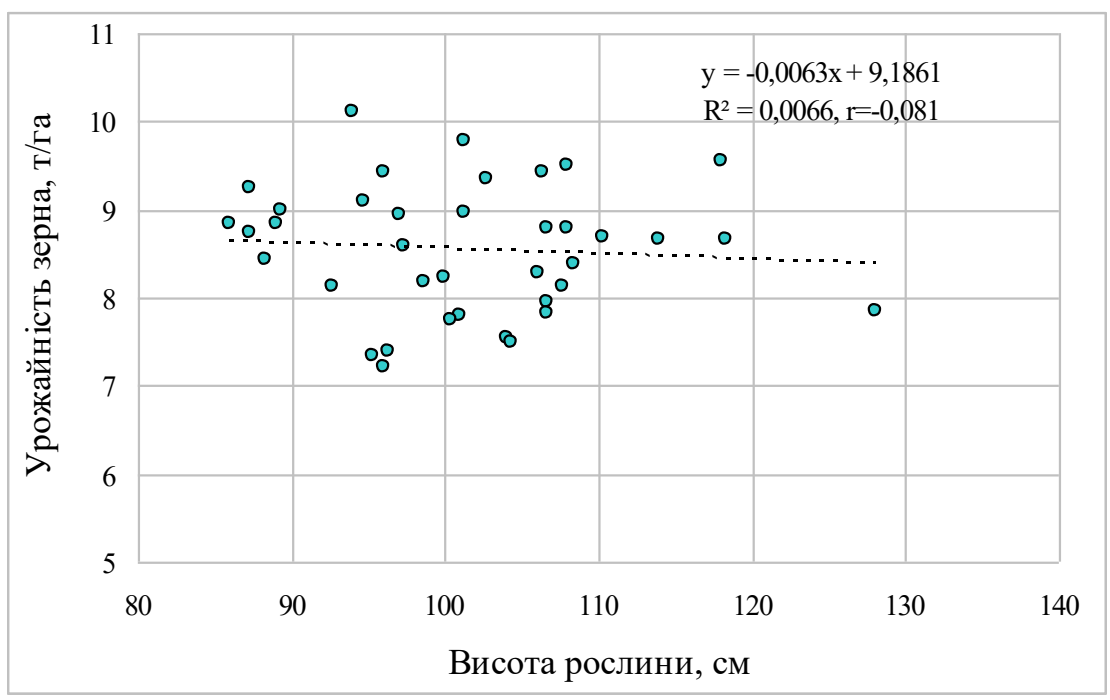

Рис. 3. Кореляційно-регресійна модель залежності урожайності зерна і висоти рослини у ліній з популяції Кошова / Кф 2-16

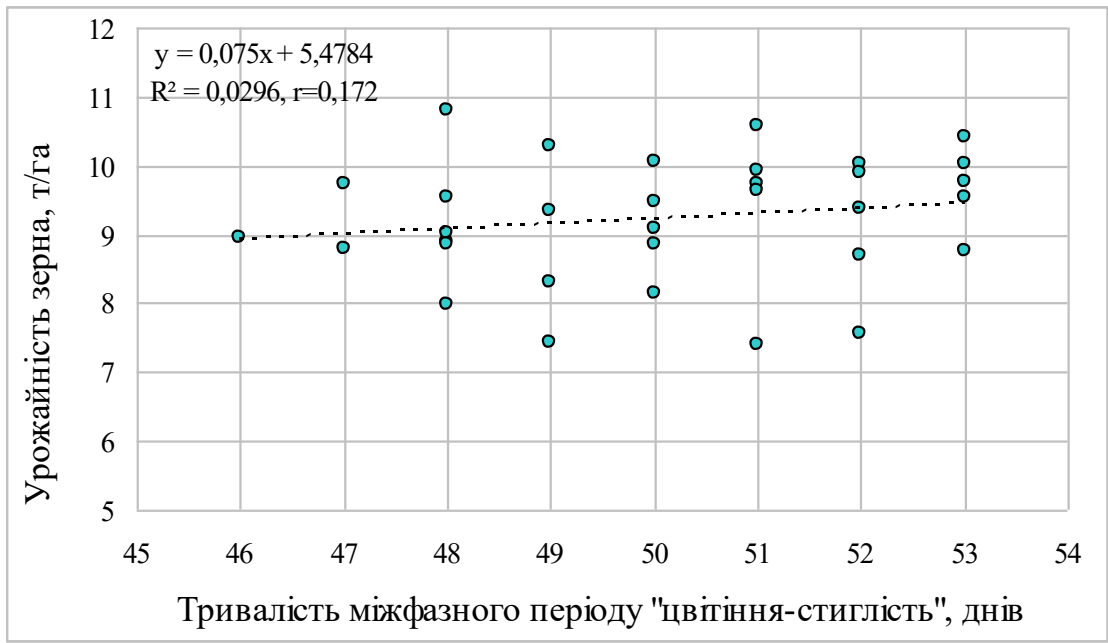

Рис. 4. Кореляційно-регресійна модель залежності висоти рослини і тривалості міжфазного періоду «цвітіння-стиелість» у ліній з популяції Кф 5-16 / Ледя 


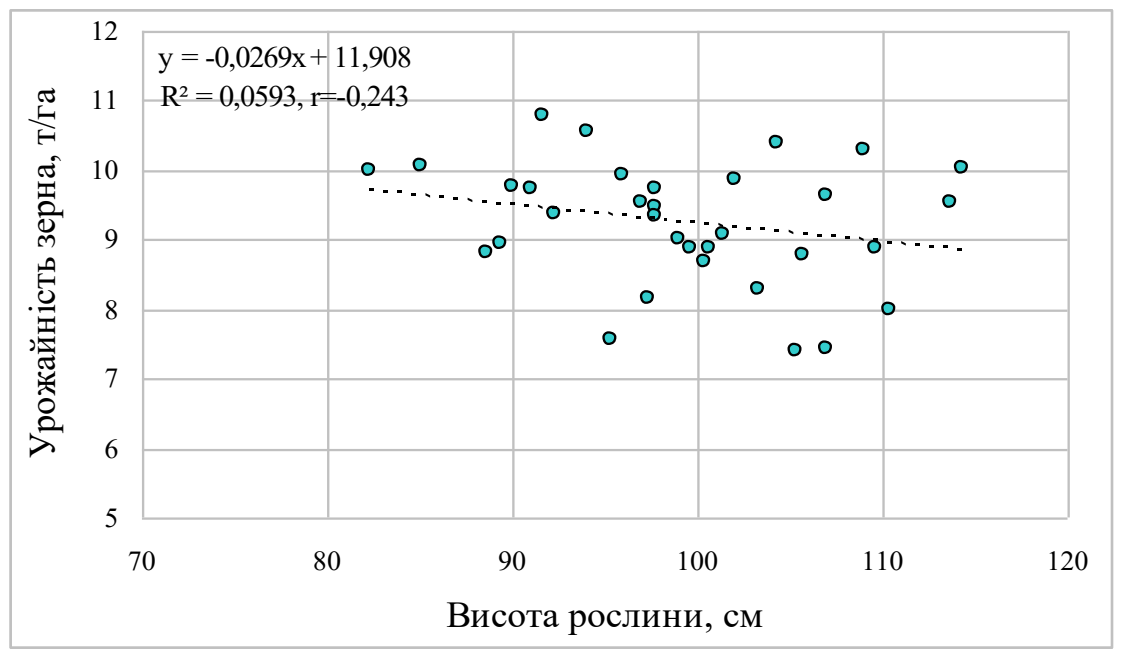

Puc. 5. Кореляційно-регресійна модель залежності урожайності зерна і висоти рослини у ліній з популяції Кф 5-16 / Ледя

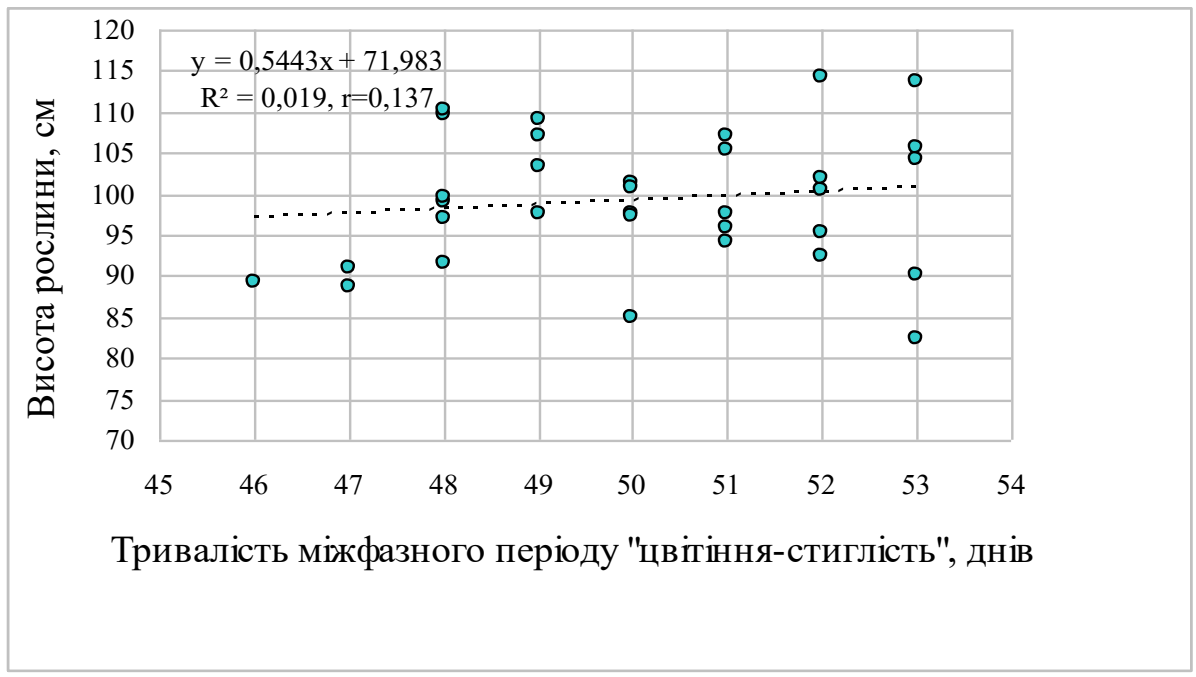

Puc. 6. Кореляційно-регресійна модель залежності урожайності зерна і тривалістю міжфазного періоду «цвітіння-стиглість» у ліній з популяції Кф 5-16 / Ледя

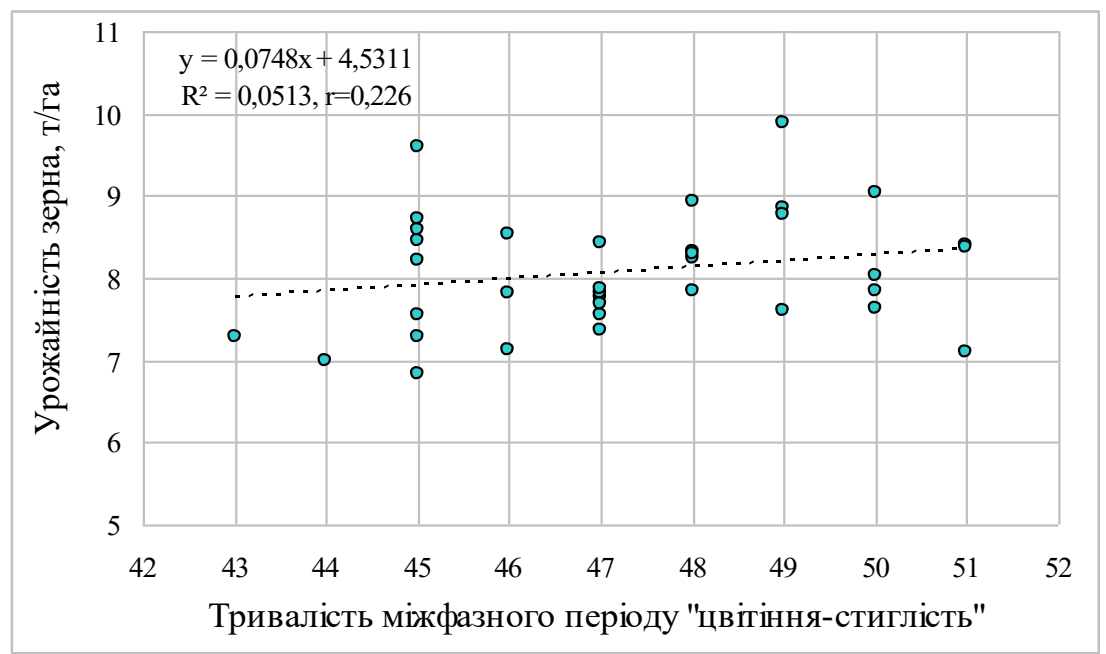

Рис. 7. Кореляційно-регресійна модель залежності урожайності зерна і тривалості міжфазного періоду «цвітіння-стиелість» у ліній з популяції Кф 2-16 / Овідій 


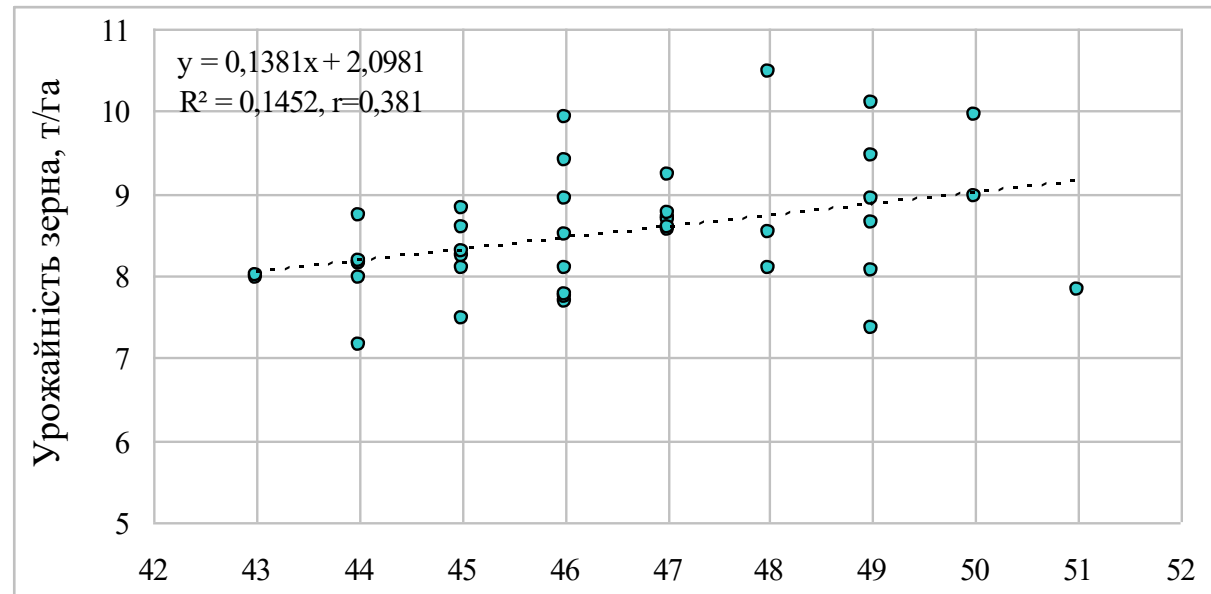

Тривалість міжфазного періоду "цвітіння-стиглість", днів

Рuc. 8. Кореляційно-регресійна модель залежності урожайності зерна і тривалості міжфазного періоду «цвітіння-стиелість» у ліній з популяції Кф 2-16 / Херсонська безоста

Параметри оптимальних ознак елітних сімей при доборах на урожайність зерна в гібридних популяціях пшениці озимої в умовах зрошення

\begin{tabular}{|l|c|c|c|c|}
\hline \multirow{2}{*}{\multicolumn{1}{|c|}{ Педігрі гібриду }} & \multicolumn{4}{|c|}{ Показники, min...max } \\
\cline { 2 - 5 } & $\begin{array}{c}\text { Висота рослин, } \\
\text { см }\end{array}$ & $\begin{array}{c}\text { Період «відростання - } \\
\text { цвітіння», діб }\end{array}$ & $\begin{array}{c}\text { Період «цвітіння- } \\
\text { стиглість», діб }\end{array}$ & $\begin{array}{c}\text { Урожайність } \\
\text { зерна, т/га }\end{array}$ \\
\hline Кошова / Кф 2-16 & $94 \ldots 102$ & $52 \ldots 53$ & $45 \ldots 46$ & $98 \ldots 102$ \\
\hline Кф5-16 / Ледя & $92 \ldots 96$ & $53 \ldots 55$ & $49 \ldots 51$ & $105 \ldots 108$ \\
\hline Кф2-16 / Овідій & $95 \ldots 106$ & $50 \ldots 52$ & $48 \ldots 49$ & $95 \ldots 99$ \\
\hline Кф2-16 / Херсон б.о. & $98 \ldots 103$ & $54 \ldots 56$ & $49 \ldots 52$ & $100 \ldots 105$ \\
\hline Кф4-16 / Овідій & $92 \ldots 98$ & $49 \ldots 50$ & $47 \ldots 49$ & $90 \ldots 97$ \\
\hline
\end{tabular}

необхідно враховувати параметри оптимальних ознак, що визначаються доборами, починаючи з $\mathrm{F}_{2}$ з наступним кореляційним аналізом в селекційних розсадниках.

Висновки. Проведення оцінок відібраних сімей за висотою рослин, термінами проходження фаз розвитку та урожайністю зерна в селекційних розсадниках дозволили з'ясувати рівень зв'язків окремих ознак та визначити найбільш вагомі маркерні для проведення доборів та корегування моделі сорту.

У проаналізованих доборів із гібридних популяцій зростання висоти рослин призводить до зменшення урожайності, а збільшення тривалості вегетації - до зростання висоти рослин.

У більшості гібридних популяцій все ж таки спостерігалась позитивна слабка залежність подовження тривалості терміну формування та наливу зернівки з урожайністю зерна, що передбачає перспективність доборів на подовження тривалості вегетації в умовах зрошення.

Для кожної гібридної популяції, що створена за участі контрастних за висотою і тривалістю вегетації батьківських компонентів, необхідно розробляти специфічний план доборів з урахуванням внутрішньопопуляційних кореляційних залежностей маркерних та результативних ознак.

\section{СПИСОК ВИКОРИСТАНОÏ ЛІТЕРАТУРИ:}

1. Лифенко С.П., Наконечний М.Ю., Нарган Т.П. Особливості селекції сортів пшениці м'якої озимої степового екотипу у зв'язку зі змінами клімату в умовах півдня України. Вісник аграрної науки. 2021. № 3(816). C. 53-62.

2. Tester M., Langridge P. Breeding technologies to increase crop production in a changing World. Science. 2010. Vol. 327, Iss. 5967. P. 818-822. doi: 10.1126/ science. 1183700 .

3. Gilliham M., Able J. A., Roy S. J. Translating knowledge about abiotic stress tolerance to breeding programmers. Plant Journal. 2017. Vol. 90, Iss. 5. P. 898-917. doi: 10.1111/tpj.13456.

4. Созінов О.О. Нові рубежі в селекції рослин. Вісник аграрної науки. 2000. № 12. С. 22-24.

5. Гадзало Я.М., Гладій М.В., Саблук П.Т., Лузан Ю.Я. Розвиток аграрної сфрери економіки в умовах децентралізації управління в Україні. Київ : Аграрна наука, 2018. 328 с.

6. Чеботар Г.О., Моцний І.І., Кульбіда М.П., Чеботар С.В. Вплив генів короткостебловості на варіацію ознак ліній м'якої озимої пшениці. Вісник Харківського національного університету імені В.Н. Каразіна. Серія: біологія. 2013. Вип. 17. № 1056. С. 95-102.

7. Волощук С.І., Юрченко Т.В. Мінливість ознаки довжина стебла у гібридно-мутантних популяціях пше- 
ниці м'якої озимої. Вісник аграрної науки. 2015. №. 5. С. $36-40$.

8. Лозінський М.В. Успадкування довжини стебла і міжвузлів пшениці м'якої озимої в $F_{1}$ та розщеплення в $\mathrm{F}_{2}$ за гібридизації різних екотипів. Вісник Сумського національного аграрного університету. Серія: Агрономія і біологія. 2016. №. 9. С. 186-191.

9. Лозінська Т.П. Успадкування господарсько цінних ознак у гібридів пшениці м'якої ярої та їх трансгресивна мінливість. Збірник наукових праць «Агробіологія». 2010. Вип. 3(74). С. 76-78.

10. Методика польових і лабораторних досліджень на зрошуваних землях / за ред. Р.А. Вожегової. Херсон : Грінь Д.С., 2014. 286 с.

11. Eberhart S. A., Russell W. A. Stability parameters for comparing varieties. Crop Science. 1966. Vol. 6. № 1. P. 36-40.

12. Орлюк А.П. Теоретичні основи селекції рослин. Херсон : Айлант, 2008. 517 с.

\section{REFERENCES:}

1. Lifenko, S. P., Nakonechnij, M. U., \& Nargan, T. P. (2021). Osoblivosti selekcii sortiv pshenici myakoi ozimoi stepovogo ekotipu u zvyazku zi zminami klimatu v umovah pivdnya Ukraïni [Features of selection of soft winter wheat varieties of steppe ecotype in connection with climate change in the south of Ukraine]. Visnik agrarnoi nauki - Bulletin of Agricultural Science, 3(816), 53-62 [in Ukrainian].

2. Tester, M., \& Langridge, P. (2010). Breeding technologies to increase crop production in a changing World. Science, 327(5967), 818-822. doi: 10.1126/science. 1183700 [in English].

3. Gilliham, M., Able, J.A., \& Roy, S.J. (2017). Translating knowledge about abiotic stress tolerance to breeding programmers. Plant Journal. 90(5). 898-917. doi: 10.1111/tpj.13456 [in English].

4. Sozinov, O.O. (2000). Novi rubezhi v selekcii roslin [New lines in the plants selection]. Visnik agrarnoi nauki-Bulletin of Agricultural Science, 12, 22-24 [in Ukrainian].

5. Gadzalo, J. M., Gladii, M. V., Sabluk, P. T., \& Luzan, Yu. (2018). Rozvytok ahrarnoyi sfery ekonomiky $v$ umovakh detsentralizatsiyi upravlinnya $v$ Ukrayini [The development of the agrarian sphere of economy in the conditions of decentralization in Ukraine]. Kyiv: Agrarna nauka, 328 [in Ukrainian].

6. Chebotar, G. O., Motsny, I. I., Kulbida, M. P., \& Chebotar, S. V. (2013). Vpliv geniv korotkosteblovosti na variaciyu oznak linij m'yakoï ozimoï pshenici [Influence of short-stem genes on the variation of soft winter wheat traits]. Visnik Harkivskogo nacionalnogo universitetu imeni V.N. Karazina. Seriya: biologiya - Bulletin of Kharkiv National University named after V.N. Karazina. Series: Biology, 17(1056), 95-102 [in Ukrainian].

7. Voloshchuk, S. I., \& Yurchenko, T. V. (2015). Minlivist oznaki dovzhina stebla u gibridno-mutantnih populyaciyah pshenici myakoï ozimoi [Variable trait stem length in hybrid-mutant populations of soft winter wheat]. Visnik agrarnoi nauki - Bulletin of Agricultural Science, 5, 36-40 [in Ukrainian].

8. Lozinskij, M. V. (2016). Uspadkuvannya dovzhini stebla i mizhvuzliv pshenici myakoi ozimoi $v \mathrm{~F} 1$ ta rozshcheplennya v F2 za gibridizaciï riznih ekotipiv. [Inheritance of stem length and internodes of soft winter wheat in F1 and splitting in F2 by hybridization of different ecotypes]. Visnik Sumskogo nacionalnogo agrarnogo universitetu. Seriya: Agronomiya i biologiya. Bulletin of Sumy National Agrarian University. Series: Agronomy and Biology, 9, 186-191 [in Ukrainian].

9. Lozinska, T.P. (2010). Uspadkuvannya gospodarsko cinnih oznak u gibridiv pshenici myakoi yaroi ta ih transgresivna minlivist [Inheritance of economically valuable traits in soft spring wheat hybrids and their transgressive variability]. Zbirnik naukovih prac Agrobiologiya Collection of scientific works Agrobiology Bila Cerkva, 3(74), 76-78 [in Ukrainian].

10. Vozhegova, R. A. (Ed.) (2014). Metodyka polovykh $i$ laboratornykh doslidzhen na zroshuvanykh zemlyakh [The methods of field and laboratory research on the irrigated lands]. Kherson: Gryn, 286 [in Ukrainian].

11. Eberhart, S.A., \& Russell, W.A. (1966). Stability parameters for comparing varieties. Crop Science, 6(1), 36-40 [in English].

12. Orliuk, A.P. (2008). Teoretychni osnovy selektsiyi roslyn [Theoretical bases of plants breeding]. Kherson: Ailant, 508 [in Ukrainian].

Жупина А.Ю., Базалій Г.Г., Усик Л.О., Марченко Т.Ю., Лавриненко Ю.О. Успадкування висоти рослин гібридами пшениці озимої різного еколого генетичного походження в умовах зрошення

Мета. Встановити характер успадкування ознаки «висота рослин», тривалість періоду «цвітіння стиглість» у гібридів пшениці озимої, створених із залученням пізньостиглих зразків західноєвропейського екотипу. Встановити кореляції цих показників з урожайністю зерна дібраних сімей. Методи. Польові дослідження проведені в Інституті зрошуваного землеробства НААН у 2016-2021 рр. Об'єктом досліджень були сучасні сорти пшениці озимої селекції Інституту, колекційні зразки західноєвропейського екотипу, що були інтродуковані з Франції та гібриди створені за їх участі. Сорти та гібриди висівались при зрошенні схемою «материнська форма, батьківська, гібрид». Методи - польові, лабораторні, селекційно-генетичні, статистичні. Результати досліджень. Представлені результати досліджень успадкування висоти рослин гібридами пшениці озимої, що створені за участі контрастних за еколого-генетичним походженням сортів. Детермінація довжини стебла рослинами $F_{1}$ пшениці м'якої озимої, створеними за участі різних екотипів, мала різноманітний характер. За схрещування напівкарликових батьківських форм у більшості спостерігалося позитивне наддомінування. У гібридів, створених за участі середньорослих генотипів з напівкарликовими успадкування, відбувалося за позитивним домінуванням. Проведення оцінок відібраних сімей за висотою рослин, термінами проходження фаз розвитку та урожайністю зерна в селекційних розсадниках дозволили з'ясувати рівень зв'язків окремих ознак та визначити найбільш вагомі маркерні для проведення доборів та корегування моделі сорту. У проаналізованих доборів з гібридних популяцій зростання висоти рослин призводить до зменшення урожайності, а збільшення тривалості вегетації - до зростання висоти рослин. Висновки. У більшості гібридних популяцій все ж таки спостерігалась позитивна, слабка залежність подовження тривалості терміну формування та наливу зернівки з урожайністю зерна, що передбачає перспективність доборів на 
подовження тривалості вегетації в умовах зрошення. Для кожної гібридної популяції, що створена за участі контрастних за висотою і тривалістю вегетації батьківських компонентів, необхідно розробляти специфічний план доборів з урахуванням внутрішньопопуляційних кореляційних залежностей маркерних та результативних ознак.

Ключові слова: сорти, гібриди, пшениця, зрошення, селекція, урожайність, висота рослин, скоростиглість.

Zhupina A.Yu., Bazaliy G.G., Usyk L.O., Marchenko T.Yu., Lavrynenko Yu.O. Inheritance of plant height by winter wheat hybrids of different ecological genetic origin under irrigation conditions

Purpose. To establish the nature of inheritance of the trait 'plant height', the duration of the period of 'flowering - maturity' in hybrids of winter wheat, created with the involvement of late-maturing specimens of Western European ecotype. Establish correlations of these indicators with grain yield of selected families. Methods. Field research was conducted at the Institute of Irrigated Agriculture of NAAS in 2016-2021. The object of research were modern varieties of winter wheat of the Institute, collection samples of Western European ecotype, which were introduced from France and hybrids created with their participation. Varieties and hybrids were sown under irrigation by the scheme 'maternal form, paternal, hybrid'. Methods - field, laboratory, breeding and genetic, statistical.
Results. The results of research on the inheritance of plant height by winter wheat hybrids, created with the participation of contrasting varieties of ecological and genetic origin, are presented. The determination of stem length by F1 soft winter wheat plants created with different ecotypes was varied. Positive dominance was observed in the majority of cross-dwarf parental forms. In hybrids created with the participation of medium-sized genotypes with semidwarf inheritance was positive dominance. Evaluations of selected families on plant height, timing and grain yield in breeding nurseries revealed the level of ties of individual traits and identified the most important markers for selection and adjustment of the variety model. In the analyzed selections from hybrid populations, the increase in plant height leads to a decrease in yield, and an increase in the duration of the growing season to an increase in plant height. Conclusions. In most hybrid populations, however, there was a positive, weak relationship between the extension of the duration of formation and filling of grain with grain yield, which suggests the prospects of selection to extend the duration of vegetation under irrigation. For each hybrid population, created with the participation of contrasting in height and duration of vegetation parent components, it is necessary to develop a specific selection plan taking into account the intra-population correlation dependence of marker and performance traits.

Key words: varieties, hybrids, wheat, irrigation, selection, yield, plant height, precocity. 